Vol. 1 No. 3 Desember 2021, e-ISSN : 2797-8842 | p-ISSN : 2797-9431

\title{
EVEKTIVITAS PEMBELAJARAN KEWARGANEGARAAN MELALUI VARIASI MODEL PEMBELAJARAN MODULER DENGAN MODEL PEMBELAJARAN MEANING FULL LEARNING
}

\author{
M. JUFRI \\ SMA Negeri 3 Takalar \\ Email :muhammadjufrimajid@gmail.com
}

\begin{abstract}
ABSTRAK
Tujuan penelitian adalah untuk mengetahui sejauh mana aktivitas siswa dalam pembelajaran Kewarganegaraan yang menerapkan variasi model pembelajaran moduler dengan model pembelajaran Meaning full learning pada kelas XII IPS 3 SMA Negeri 3 Takalar dan untuk mengetahui efektivitas pembelajaran Kewarganegaraan melalui variasi model pembelajaran moduler dengan model pembelajaran Meaning full Learning pada siswa kelas X SMA Negeri 3 Takalar. Hasil penelitian menunjukkan bahwa: (1) penerapan model pembelajaran moduler dan Meaning full learning secara bervariasi dalam pembelajaran Kewarganegaraan dapat meningkatkan aktivitas belajar siswa yang meliputi minat mengerjakan modul, kreativitas mengerjakan modul, kemandirian mengerjakan modul, menyelesaikan modul tepat waktu, mutu hasil modul, minat mengikuti diskusi mengajukan pendapat/ tanggapan, mencatat hal penting tentang diskusi, mentaati aturan diskusi, dan mutu hasil diskusi, (2) penerapan model pembelajaran moduler dan model pembelajaran Meaning full learning secara bervariasi dapat mengefektifkan pembelajaran Kewarganegaraan. Hal ini dapat dilihat data hasil observasi terhadap aktivitas siswa yang meningkat dari $69,92 \%$ pada siklus I menjadi $81,58 \%$ pada siklus II dan nilai rata-rata hasil penilaian kognitif siswa yang juga meningkat dan mencapai KKM, yaitu dari 70,07 pada siklus I menjadi 84,33 pada siklus II, dan (3) peranan guru dalam proses belajar mengajar yang menerapkan model pembelajaran moduler dan model pembelajaran MFL sangat penting sebagai pendukung peningkatan aktivitas belajar siswa dan peningkatan prestasi belajar.
\end{abstract}

Kata Kunci: Efektivitas Pembelajaran, Variasi, Moduler dan MFL

\section{ABSTRACT}

The purpose of the study was to determine the extent to which student activities in civics learning apply variations of the modular learning model with the Meaning full learning learning model in class XII IPS 3 SMA Negeri 3 Takalar and to determine the effectiveness of civics learning through variations of the modular learning model with the Meaning full Learning learning model. in class X SMA Negeri 3 Takalar. The results showed that: (1) the application of the modular learning model and Meaning full learning in various variations in Civics learning can increase student learning activities which include interest in working on modules, creativity in working on modules, independence in working on modules, completing modules on time, quality of module results, interest in following the discussion, submitting opinions/responses, noting important things about the discussion, obeying the discussion rules, and the quality of the discussion results, (2) the application of the modular learning model and the Meaning full learning learning model in various ways can make Civics learning effective. This can be seen from the observational data on student activities which increased from $69.92 \%$ in the first cycle to $81.58 \%$ in the second cycle and the average value of the students' cognitive assessment results which also increased and reached the KKM, namely from 70.07 in the first cycle to 84.33 in the second cycle, and (3) the role of the teacher in the teaching and learning process that applies the modular learning model and the MFL learning model is very important as a supporter of increasing student learning activities and improving learning achievement.

Keywords: Effectiveness of Learning, Variation, Modular and MFL 


\section{PENDAHULUAN}

Idealnya sebuah proses pembelajaran yang baik adalah proses pembelajaran yang efektif, yang mampu mengantar peserta didik pada pencapaian tujuan pembelajaran yang optimal. Kondisi ini hanya dimungkinkan jika didukung oleh komponen komponen pembelajaran yang bersinergi dengan baik satu sama lain. Komponen komponen yang dimaksud adalah guru, siswa, sarana dan prasarana, strategi, model dan metode pembelajaran, serta lingkungan.

Berkaitan dengan faktor-faktor tersebut di atas, salah satu masalah yang sering dihadapi dunia pendidikan di Indonesia dewasa ini, khususnya mata pelajaran Kewarganegaraan adalah masalah sulitnya mencapai efektivitas pembelajaran. Dalam proses pembelajaran di kelas, masih banyak guru yang menerapkan model strategi pembelajaran yang tidak sesuai dengan karakteristik mata pelajaran Kewarganegaraan, di mana proses pembelajaran cenderung diarahkan pada pembentukan aspek intelektual (kemampuan kognitif). Padahal pendidikan Kewarganegaraan semestinya diarahkan pada pembentukan sikap dan moral. Selain itu, sulitnya mencapai efektivitas dalam pembelajaran Kewarganegaraan juga disebabkan oleh penyampaian materi pelajaran yang berpusat pada guru dan bersifat monoton, sehingga kreativitas, kemandirian, perhatian, minat, dan motivasi belajar siswa menjadi rendah, yang mengakibatkan proses dan hasil belajar juga rendah.

Oleh karena itu, untuk mengatasi masalah efektivitas yang disebabkan oleh hal-hal tersebut di atas diperlukan model-model strategi pembelajaran yang sesuai dengan karakteristik mata pelajaran Kewarganegaraan dan berpusat pada siswa. Adapun model-model yang digunakan peneliti dalam hal ini adalah model pembelajaran moduler (Pembelajaran yang bermakna atau Meaning full learning (MFL)

Dengan demikian, maka kajian penelitian tindakan kelas ini adalah "Efektivitas Pembelajaran Kewarganegaraan melalui Variasi Model Pembelajaran Moduler dengan Model Pembelajaran Meaning full learning pada siswa kelas XII IPS 3 SMA Negeri 3 Takalar".

\section{METODE PENELITIAN}

Penelitian ini adalah Penelitian Tindakan Berbasis Kelas, tindakan berupa intervensi terhadap proses kegiatan pembelajaran di kelas, maupun terhadap hasil belajar siswa yang mengarah kepada penyelesaian masalah-masalah yang dihadapi siswa dalam belajar, khususnya mengenai efektivitas pembelajaran Kewarganegaraan, dengan maksud untuk meningkatkan proses dan hasil belajar siswa melalui variasi model pembelajaran moduler dengan model pembelajaran Meaning full learning.

Prosedur penelitian tindakan kelas ini dilaksanakan berupa proses berdaur (siklus), yang terdiri dari 4 tahap, yaitu: (1) Perencanaan (Planning): mengkaji standar kompetensi dan kompetensi dasar, mengkaji silabus dan sistem penilaian, menentukan KKM yaitu 70, menyusun rencana pelaksanaan pembelajaran model moduler dan MFL, membuat modul, membuat instrumen yang digunakan dalam siklus PTK, dan menyusun alat evaluasi pembelajaran, (2) Pelaksanaan Tindakan (Action): menyajikan materi pelajaran, menerapkan model pembelajaran moduler dan MFL, siswa diberi kesempatan bertanya dan menanggapi, (3) Pengamatan (Observation): mengamati dan mencatat jalannya proses belajar mengajar, aktivitas siswa dalam belajar, dan aktivitas guru dalam mengajar, (4) Refleksi (Reflecting): menganalisis hasil pengamatan dan melakukan evaluasi terhadap proses dan hasil pembelajaran.

Penelitian ini dilaksanakan di SMA Negeri 3 Takalar di kelas XII IPS 3. Jumlah siswa adalah 30 orang, yang terdiri dari 7 siswa laki-laki dan 23 siswa perempuan. Pemilihan kelas XII IPS 3 sebagai subyek penelitian bertujuan untuk memperbaiki dan meningkatkan proses dan hasil belajar kelas ini termasuk salah satu kelas yang bermasalah dalam soal efektivitas pembelajaran. Penelitian ini dilaksanakan pada semester ganjil tahun pelajaran 2018/2019, yaitu bulan Agustus sampai dengan November 2018. Penentuan waktu penelitian merigacu pada kalender akademik sekolah, karena PTK memerlukan beberapa siklus yang membutuhkan 
proses belajar mengajar yang efektif di kelas.Karena keterbatasan waktu, maka PTK ini hanya dibagi dalam 2 siklus, yaitu siklus I dan siklus Il. Tujuan dari masing-masing siklus adalah untuk meningkatkan efektivitas pembelajaran dalam mata pelajaran Kewarganegaraan, melalui tindakan berupa variasi model pembelajaran moduler dengan meaning full learning.

\section{HASIL DAN PEMBAHASAN}

\section{Hasil}

Hasil penelitian diuraikan dalam tahapan yang berupa siklus pembelajaran yang dilakukan dalam proses belajar mengajar di kelas. Dalam penelitian ini, pembelajaran dilakukan dalam dua siklus, di mana tiap siklus terdiri dari tiga pertemuan, yaitu pertemuan pertama, kedua, dan ketiga sebagaimana pemaparan berikut ini.

\section{Siklus I}

a. Perencanaan

Pada tahap ini, peneliti melakukan analisis kurikulum untuk menentukan kompetensi dasar, menentukan indikator, tujuan pembelajaran, materi, dan model pembelajaran, menyiapkan modul, membuat instrumen, dan menyusun alat evaluasi, yang kesemuanya itu terangkum dalam RPP (Rencana Pelaksanaan Pembelajaran). Kegiatan-kegiatan tersebut dilakukan selama tiga kali pertemuan. Adapun mengenai standar kompetensi, kompetensi dasar, indikator, tujuan pembelajaran, materi, model pembelajaran, modul, instrumen, dan alat evaluasi selama tiga kali pertemuan .

Pelaksanaan

Tahap ini merupakan implementasi atau pelaksanaan RPP yang telah dibuat dengan segala kelengkapannya untuk diterapkan dalam proses belajar mengajar di kelas. Kegiatan pembelajaran Kewarganegaraan untuk tiap pertemuan perminggu dilaksanakan dalam 2 (dua) jam pelajaran (90 menit) sesuai dengan alokasi waktu yang telah ditentukan oleh K13), dengan penjatahan waktu satu jam pertama untuk kegiatan pembelajaran yang menggunakan model moduler dan satu jam kedua untuk kegiatan pembelajaran yang menggunakan model MFL. Adapun tujuan pemberian jatah waktu satu jam pertama untuk mengerjakan tugas modul adalah agar siswa dapat menguasai konsep-konsep, prinsip prinsip, atau nilai-nilai yang merupakan materi dalam MFL sehingga kegiatan MFLdapat berjalan lancar.

Pada pertemuan pertama yang membahas tentang "Perlindungan dan penegakan hukum", aktivitas pembelajaran dimulai dengan kegiatan apersepsi, penjelasan pokok bahasan, tujuan pembelajaran, dan metode/model yang digunakan oleh guru dalam proses belajar mengajar tersebut. Selanjutnya, para siswa melakukan kegiatan belajar dengan mengerjakan penugasan terstruktur (PT) yang terdapat dalam modul dalam bentuk Uji Kompetensi yang berisi soal-soal uraian. Setelah sampai pada batas waktu yang telah ditentukan, para siswa mengumpulkan modulnya untuk diperiksa. Adapun teknik pemeriksaan yang digunakan adalah pemeriksaan silang, yaitu siswa memeriksa hasil pekerjaan temannya, tidak boleh memeriksa hasil pekerjaan sendiri, dan tidak boleh memberitahu pekerjaan siapa yang diperiksa. Hal ini dimaksudkan untuk menjaga objektivitas penilaian. Selanjutnya, guru memberikan pembahasan singkat tentang jawaban soal-soal yang telah dipersiapkan dan setelah itu pekerjaan siswa dikumpulkan kembali untuk dinilai. Tentu saja, selama dalam proses pemeriksaan oleh para siswa, guru harus berkeliling mengadakan pengawasan agar pemeriksaan benar-benar obyektif. Sebelum mengakhiri pembelajaran modul ini, guru memberikan tugas kegiatan mandiri tidak terstruktur (KMTT) yang soalnya tercantum dalam modul.

Setelah kegiatan pembelajaran modul selesai, maka proses pembelajaran dilanjutkan dengan kegiatan pembelajaran model MFL Sebelum model pembelajaran ini dimulai, guru terlebih dahulu membagikan hand out kepada siswa yang berisi tentang topik pembahasan (Perlindungan dan penegakan hukum) dan langkah-langkah pelaksanaannya. Siswa diberi kesempatan menanyakan hal-hal yang belum jelas dan guru memberikan penjelasan seperlunya. 
Pada awal kegiatan pembelajaran yang menerapkan variasi model pembelajaran moduler dengan MFL, pelaksanaan belum sesuai dengan harapan. Hal ini disebabkan oleh halhal sebagai berikut:

1) Siswa pada umumnya belum mengerti model pembelajaran moduler dan MFL karena mereka tidak biasa belajar dengan kedua model tersebut apalagi divariasikan dalam satu pertemuan.

2) Sebagian siswa terlambat menyelesaikan tugas modulnya karena kurangnya buku paket yang dimiliki, bahkan ada beberapa orang siswa yang tidak membawa modulnya karena lupa atau ketinggalan di rumah.

3) Sebagian siswa malas mengerjakan modul sehingga tidak selesai sampai pada batas waktu yang telah ditentukan.

4) Sebagian siswa hanya meniru hasil pekerjaan orang lain tanpa mengalami proses belajar.

5) Proses diskusi/dialog dengan model MFL seringkali dimonopoli oleh siswa yang pintar bicara.

6) Sebagian siswa masih ada yang malu-malu, ragu-ragu, atau tidak berani untuk mengemukakan pendapat dalam pembelajaran model MFL.

7) Sebagian siswa kurang memiliki kemampuan komunikasi verbal yang baik sehingga sulit mengungkapkan ide atau pendapat terutama mengenai masalahmasalah nilai yang bersifat abstrak.

8) Sebagian siswa bersikap apatis atau kurang aktif mengikuti proses pembelajaran model MFL. Hal ini mungkin karena materi pelajaran yang masih asing bagi mereka.

Untuk mengatasi masalah tersebut, maka upaya yang dilakukan adalah sebagai berikut:

1) Guru secara intensif menjelaskan langkah-langkah model pembelajaran moduler dan MFL.

2) Guru memotivasi siswa untuk memiliki buku paket sendiri agar dapat menjawab soal modul dengan baik sehingga dapat menyelesaikan tugas modul tepat waktu dan memberikan tugas tambahan bagi siswa yang lupa membawa modulnya.

3) Guru memberikan tugas yang menarik minat dan perhatian siswa.

4) Guru melakukan kontrol atau pengawasan yang sistematis terhadap tugas yang diberikan sehingga mendorong siswa untuk belajar dengan sungguh-sungguh.

5) Guru mengatur giliran kesempatan berbicara yang sama kepada setiap siswa.

6) Guru menciptakan iklim yang kondusif, suasana santai, dan tidak terlalu kaku agar siswa termotivasi untuk berani mengemukakan pendapatnya. Di samping itu, guru juga memberikan penguatan, misalnya memberikan nilai tambah kepada setiap siswa yang mampu mengungkapkan ide atau pendapat brilian atau jawaban pemecahan masalah.

7) Guru menunjukkan buku-buku referensi yang relevan dengan pokok permasalahan yang dibahas dalam MFL untuk dibaca oleh siswa agar dapat meningkatkan kemampuan komunikasi verbalnya. Selain itu, guru juga harus memberi Forsi yang lebih besar untuk berbicara kepada siswa tersebut dalam setiap kesempatan proses belajar mengajar sehingga siswa terlatih untuk berkomunikasi secara verbal.

8) Guru menghubungkan materi pelajaran dengan pengalaman sehari-hari siswa dan memilih topik permasalahan MFL yang lebih menarik, aktual, kontroversial, atau dilematis, dan yang tidak kalah pentingnya adalah guru juga memberikan tugas untuk membuat laporan tentang jalannya proses pembelajaran MFL, misalnya masalah yang dibahas dan alternatifalternatif pemecahannya. Dengan cara demikian, maka para siswa akan terlibat aktif dałam keseluruhan proses pembelajaran MFL, mulai dari awal hingga akhir kegiatan pembelajaran.

Pada pertemuan kedua, proses belajar mengajar dengan penerapan model pembelajaran moduler dan MFL kembali ditempuh untuk mengkaji materi tentang "Perlindungan dan Penegakan hukum". Sebelumnya guru terlebih dahulu mengecek hasil PR siswa, yaitu kegiatan mandiri tidak terstruktur. Pada pertemuan ini, antusias siswa sudah mulai tampak dari 
partisipasinya mengikuti pelajaran, di mana siswa sudah bisa menyesuaikan diri dengan jalannya proses belajar mengajar yang menggunakan model pembelajaran moduler dan MFL. Misalnya, sebagian besar siswa sudah dapat menyelesaikan penugasan terstruktur (PT) maupun kegiatan mandiri tidak terstruktur (KMTT) dałam modulnya dengan tepat waktu, mandiri dan bertanggung jawab alias tidak menyontek hasil pekerjaan temannya. Dałam proses belajar mengajar model MFL, keaktifan siswa sudah mulai tampak, baik dałam memberikan tanggapan, pendapat, pertanyaan, maupun dałam menjawab pertanyaan, dan jumlah yang aktif berbicara mulai meningkat. Hanya saja, kualitasnya masih kurang. Seringkali pembicaraan siswa melenceng dari pokok permasalahan dan siswa memberanikan diri berbicara hanya karena termotivasi oleh reinforcement (penguatan) yang diberikan guru.

Adapun gambaran mengenai hasil kegiatan pembelajaran yang perlu diperbaiki pada pertemuan kedua Siklus I ini adalah sebagai berikut:

1) Masih ada beberapa siswa (sebagian kecil) yang belum menyelesaikan modulnya.

2) Kualitas hasil pekerjaan modul berupajawaban uraian kurang memuaskan.

3) Kemampuan siswa dalam mengembangkan ide-ide pemecahan masalah masih kurang.

4) Fokus pada pokok permasalahan masih perlu ditingkatkan.

5) Kemampuan siswa dalam menyimpulkan materi diskusi masih perlu diperbaiki.

Terhadap permasalahan-permasalahan tersebut, maka ditempuh langkahlangkah alternatif pemecahan masalah sebagai berikut:

1) Guru memberikan perhatian khusus terhadap kelompok siswa tersebut karena mungkin saja mereka mengalami kesulitan belajar. Misalnya, guru menanyakan soal-soal yang dianggap sulit dijawab dan di mana dapat ditemukan sumber jawabannya.

2) Guru membahas soal-soal modul terutama soal yang sulit dijawab Oleh siswa. Misalnya, guru menjelaskan teknik menjawab soal analisis tingkat tinggi agar kualitas jawaban siswa dapat ditingkatkan.

3) Guru memotivasi siswa untuk banyak membaca dan banyak melatihkan cara berpikir untuk memecahkan masalah.

4) Guru menuntun siswa untuk berpikir logis

Guru meminta siswa untuk selalu memperhatikan dan mencatat materi-materi inti dan penting dari suatu pembahasan masalah sehingga apa yang dicatat dapat diambil sebagai kesimpulan.

Pada akhir pertemuan, guru memberikan PR berupa Kegiatan Mandiri Tidak Terstruktur yang tercantum dalam diktat.

Memasuki pertemuan ketiga dalam Siklus I dengan materi "Semangat Kebangsaan, Nasionalisme, dan Patriotisme dalam Kehidupan Bermasyarakat, Berbangsa, dan Bernegara", guru kembali mengkaji materi dengan menerapkan model pembelajaran moduler dan MFL. Sebagaimana biasa, guru terlebih dahulu memeriksa PR siswa (Kegiatan Mandiri Tidak Terstruktur).

Dalam proses pembelajaran yang menerapkan model pembelajaran moduler, para siswa ditugaskan untuk menjawab soal-soal Evaluasi dalam modul, yang terdiri dari soal pilihan ganda dan uraian. Materi soal-soal Evaluasi ini diambil dari materi pertemuan pertama sampai pertemuan ketiga. Walaupun jumlah soal dalam Evaluasi ini lebih banyak daripada jumlah soal Uji Kompetensi, namun sebagian besar siswa dapat menyelesaikan pada waktunya (satu jam pelajaran). Hal ini dimungkinkan karena materinya sebagian besar sudah pernah dibahas dalam pertemuan pertama dan kedua, dan juga siswa sudah disampaikan pada pertemuan sebelumnya untuk mempelajari soal-soal Evaluasi tersebut.

Demikian pula dalam proses pembelajaran yang menerapkan model pembelajaran MFL, sebagian besar siswa dapat terlibat aktif dalam diskusi karena materi yang didiskusikan sudah pernah dipelajari oleh siswa sewaktu masih di SD dan SMP.

Pada akhir siklus pertama, terutama pada pertemuan ketiga, dari hasil pengamatan guru dan kolaborasi dengan teman sejawat dapat disimpulkan, bahwa: 
Vol. 1 No. 3 Desember 2021, e-ISSN : 2797-8842 | p-ISSN : 2797-9431

1) Sebagian besar siswa mulai antusias mengerjakan modul dan dapat menyelesaikan tugas modulnya tepat waktu dan tanpa menyontek.

2) Kualitas dan kuantitas komunikasi verbal siswa dalam dialog MFL mulai meningkat.

3) Keaktifan siswa dalam proses pembelajaran yang menerapkan variasi model pembelajaran moduler dengan MFL mulai meningkat.

c. Observasi

1) Hasil observasi mengenai aktivitas siswa dalam proses belajar mengajar selama siklus I dapat dilihat pada tabel berikut:

Tabel 1. Perolehan Skor Aktivitas Siswa dalam Proses Belajar Mengajar Kewarganegaraan Model Pembelajaran Moduler dan MFL Siklus I

\begin{tabular}{|l|c|c|c|c|}
\hline \multicolumn{1}{|c|}{ Jenis Aktivitas Siswa } & $\begin{array}{c}\text { Skor } \\
\text { Perolehan }\end{array}$ & $\begin{array}{c}\text { Skor } \\
\text { Ideal }\end{array}$ & Persentase & Ket. \\
\hline Minat mengerjakan modul & 92 & 120 & 76,67 & Tertinggi \\
\hline Kreativitas mengerjakan modul & 88 & 120 & 73,33 & \\
\hline Kemandirian mengerjakan modul & 91 & 120 & 75,83 & \\
\hline Menyelesaikan modul tepat waktu & 85 & 120 & 70,83 & \\
\hline Mutu hasil modul & 90 & 120 & 75 & \\
\hline Minat mengikuti diskusi MFL & 90 & 120 & 75 & \\
\hline Mengajukan pendapat/ tanggapan & 78 & 120 & 65 & \\
\hline Mencatat hal penting tentang diskusi & 74 & 120 & 61,67 & \\
\hline Mentaati aturan diskusi & 87 & 120 & 72,50 & \\
\hline Mutu hasil Diskusi & 64 & 120 & 53,33 & Terendah \\
\hline Rata-rata & 83,90 & 120 & 69,92 & Sedang \\
\hline
\end{tabular}

2) Hasil observasi mengenai aktivitas guru dalam proses belajar mengajar selama siklus I dapat dilihat dari hasil observasi terhadap aktivitas guru dalam proses belajar mengajar yang hanya mencapai 64,58 .

1. Hasil analisis deskriptif terhadap nilai evaluasi belajar Kewarganegaraan siswa kelas XII IPS 3 SMA Negeri 3 Takalar pada akhir Siklus I dapat dilihat pada table berikut:

Tabel 2 Data Statistik Hasil Evaluasi Belajar Kewarganegaraan Siswa pada Akhir Siklus I

\begin{tabular}{|l|c|}
\hline \multicolumn{1}{|c|}{ Statistik } & Jumlah \\
\hline Banyaknya subyek penelitian & 30 \\
\hline Nilai rata-rata & 70,07 \\
\hline Standar deviasi & 17,21 \\
\hline Nilai tertinggi & 92 \\
\hline
\end{tabular}




\begin{tabular}{|l|c|}
\hline Nilai terendah & 40 \\
\hline Jumlah siswa yang mencapai KKM & 21 \\
\hline Nilai afektif & Tinggi \\
\hline
\end{tabular}

d. Refleksi

Hasil-hasil yang dicapai pada siklus I adalah sebagai berikut:

1) Keaktifan siswa dalam proses pembelajaran yang menerapkan variasi model pembelajaran moduler dengan MFL mulai meningkat. Dari Tabel 1 di atas, terlihat bahwa pada umumnya aktivitas siswa terutama dalam mengerjakan modul, memiliki persentase skor yang tinggi dengan skor tertinggi adalah 76,67\%, sedangkan aktivitas siswa dalam diskusi MFL persentasenya sedang sedang saja dengan nilai terendah 53,33\%.

2) Secara umum, siswa belum terbiasa dengan kondisi belajar yang menerapkan model pembelajaran moduler dan MFL secara bervariasi. Hal ini dapat dilihat dari hasil observasi terhadap aktivitas siswa dalam proses belajar mengajar hanya mencapai 69,92. Artinya, aktivitas siswa dalam proses belajar mengajar masih tergolong sedang.

3) Secara umum, guru belum terbiasa menciptakan kondisi belajar yang menerapkan model pembelajaran moduler dan MFL secara bervariasi. Hal ini dapat dilihat dari hasil observasi terhadap aktivitas guru dalam proses belajar mengajar hanya mencapai 64,58. Artinya, aktivitas guru dalam proses belajar mengajar masih tergolong sedang (lihat Lampiran).

4) Hasil evaluasi siswa pada siklus I mencapai rata-rata 70,07. Artinya, nilai ratarata hasil evaluasi belajar siswa tergolong tinggi. Hal ini tentunya tidak lepas dari meningkatnya aktivitas siswa dari pertemuan pertama hingga pertemuan ketiga, baik aktivitas mengerjakan modul maupun aktivitas diskusinya.

5) Masih ada beberapa siswa yang belum bisa menyelesaikan tugas modul tepat waktu. Hal ini karena siswa tersebut kurang serius dalam belajar.

6) Masih ada beberapa siswa yang belum mampu melakukan komunikasi verbal dalam diskusi/dialog.

Untuk mengatasi kelemahan proses belajar mengajar pada siklus I, maka pada pelaksanaan siklus II dapat dibuat perencanaan sebagai berikut:

1) Memberikan motivasi kepada siswa agar lebih aktiflagi dalam belajar.

2) Memberikan bimbingan intensif kepada siswa yang mengalami kesulitan belajar.

3) Meningkatkan pemberian penguatan (reinforcement) dan penghargaan (reward).

4) Guru memperbaiki cara mengajarnya sehingga kekurangannya dalam melaksanakan proses pembelajaran dapat diperbaiki.

\section{Siklus II}

Siklus II dilaksanakan sebanyak 3 kali pertemuan dan setiap pertemuan berlangsung selama 2 x 45 menit. Seperti pada siklus I, maka siklus II ini juga terdiri dari tahap perencanaan, pelaksanaan, observasi, dan refleksi.

a. Perencanaan

Perencanaan pada siklus II pada umumnya berdasarkan pada hasil perbaikan dari perencanaan siklus I, yaitu pemberian motivasi kepada siswa agar lebih aktif Iagi dalam belajar, pemberian bimbingan intensif kepada siswa yang mengalami kesulitan belajar, peningkatan pemberian penguatan (reinforcement) dan penghargaan (reward), dan perbaikan cara mengajar guru.

Adapun mengenai standar kompetensi, kompetensi dasar, indikator, tujuan pembelajaran, materi, model pembelajaran, modul, instrumen, dan alat evaluasi selama tiga kali pertemuan dalam siklus II ini dapat dilihat pada bagian Lampiran.

b. Pelaksanaan 
Secara terperinci kegiatan proses belajar mengajar mulai dari pertemuan pertama hingga pertemuan ketiga pada siklus II digambarkan sebagai berikut: pada pertemuan pertama, siswa diperkenalkan materi baru, yaitu "Pengertian Sistem Hukum dan Peradilan Nasional", dan pembahasan materi dilakukan dengan penerapan model pembelajaran moduler dan MFL secara bervariasi sebagaimana yang dilakukan pada siklus I. Pada kegiatan awal ini, guru membuka pelajaran dengan melakukan apersepsi, menyampaikan tujuan pembelajaran, dan memberikan motivasi dengan memberikan beberapa pertanyaan pancingan sebagai pengantar memasuki materi pelajaran.

Suasana proses pembelajaran sudah berjalan lancar. Penugasan terstruktur (PT) untuk menjawab soal-soal modul dalam bentuk Uji Kompetensi yang diberikan guru kepada siswa mampu diselesaikan dengan baik oleh sebagian besar siswa. Demikian pula dalam kegiatan tatap muka (TM) yang berupa diskusi model MFL, siswa lebih bergairah berpartisipasi dibanding pada pertemuan-pertemuan sebelumnya, di mana siswa aktif mengemukakan pendapat dan tanggapan. Hal ini karena guru merancang tema diskusi tentang masalah hukum dan peradilan yang dikaitkan dengan kehidupan sehari-hari yang dialami oleh para siswa.

Pada akhir pertemuan pertama dalam siklus II, beberapa orang siswa sudah dapat membuat kesimpulan tentang materi pokok pembahasan dan dapat menjawab pertanyaan posttest yang diajukan secara lisan oleh guru. Setelah berdoa bersama siswa, guru menutup pelajaran.

Pada pertemuan kedua dan ketiga dalam siklus II, materi yang dibahas oleh para siswa adalah sama, yaitu tentang "Peranan Lembaga-lembaga Peradilan", hanya saja penekanannya berbeda. Pertemuan kedua menekankan tentang materi "Peranan Lembaga-lembaga Peradilan", sedangkan pertemuan ketiga menekankan materi "Prosedur Penegakan Hukum".

Sebagaimana biasanya, guru memulai aktivitas pembelajaran dengan berdoa bersama siswa, mengabsen, menyampaikan pokok bahasan dan tujuan pembelajaran, melakukan apersepsi, motivasi, dan pre-test.

Dalam proses belajar mengajar (kegiatan inti), para siswa kembali membahas materi dengan model pembelajaran moduler yang divariasikan dengan MFL. Yang perlu digarisbawahi dalam siklus II ini, khususnya pada pertemuan ketiga adalah adanya perubahan yang signifikan dari aktivitas belajar siswa. Misalnya, dalam kegiatan pembelajaran yang menggunakan modul, makin banyak siswa yang rajin mengerjakan modul, bahkan banyak yang mampu menyelesaikan modulnya lebih cepat dari waktu yang disediakan sehingga pemeriksaan pun dapat dilakukan lebih awal. Selain itu, kualitas dan kuantitas hasil pekerjaan modul juga meningkat.

Sementara itu, dalam kegiatan pembelajaran diskusi MFL, jumlah siswa yang aktif dalam diskusi juga meningkat, di mana beberapa siswa yang selama ini dianggap pendiam tanpa canggung dan tanpa malu-malu aktif menanggapi dan mengemukakan pendapatnya, bahkan dalam beberapa kesempatan mereka berebutan untuk mengemukakan pendapat atau tanggapannya. Di samping itu, kualitas verbal siswa dalam berbicara juga mengalami kemajuan.

Sebagai indikator adanya kemajuan pesat yang dicapai oleh siswa adalah meningkatnya antusias siswa dalam menjawab dengan baik sejumlah pertanyaan yang diajukan oleh guru sebagai penilaian proses. Hal ini tentu hanya dapat dilakukan oleh siswa yang tekun memperhatikan jalannya proses pembelajaran.

Kegiatan pembelajaran pada pertemuan ketiga dalam siklus II ini ditutup dengan kegiatan menarik kesimpulan yang sudah biasa dilakukan oleh siswa, pemberian tugas (PR) berupa kegiatan mandiri tidak terstruktur (KMTT), kegiatan tindak lanjut untuk pertemuan berikutnya, post-test, dan berdoa bersama.

c. Observasi

1) Hasil observasi mengenai aktivitas siswa dalam proses belajar mengajar selama siklus II dapat dilihat pada tabel berikut: 
Vol. 1 No. 3 Desember 2021, e-ISSN : 2797-8842 | p-ISSN : 2797-9431

Tabel 3. Perolehan Skor Aktivitas Siswa dalam Proses Belajar Mengajar Kewarganegaraan Model Pembelajaran Moduler dan MFL Siklus II

\begin{tabular}{|l|c|c|c|c|}
\hline \multicolumn{1}{|c|}{ Jenis Aktivitas Siswa } & $\begin{array}{c}\text { Skor } \\
\text { Perolehan }\end{array}$ & Skor Ideal & Persentase & Ket. \\
\hline Minat mengerjakan modul & 108 & 120 & 90 & \\
\hline Kreativitas mengerjakan modul & 87 & 120 & 72,50 & Terendah \\
\hline Kemandirian mengerj akan modul & 95 & 120 & 79,17 & \\
\hline Menyelesaikan modul tepat waktu & 100 & 120 & 83,33 & \\
\hline Mutu hasil modul & 104 & 120 & 86,67 & \\
\hline Minat mengikuti diskusi MFL & 97 & 120 & 80,83 & \\
\hline Mengajukan pendapat/ tanggapan & 89 & 120 & 74,17 & \\
\hline $\begin{array}{l}\text { Mencatat hal penting tentang } \\
\text { diskusi }\end{array}$ & 95 & 120 & 79,17 & \\
\hline Mentaati aturan diskusi & 113 & 120 & 94,17 & Tertinggi \\
\hline Mutu hasil Diskusi & 91 & 120 & 75,83 & \\
\hline Rata-rata & 97,90 & 120 & 81,58 & Tinggi \\
\hline
\end{tabular}

2) Hasil observasi mengenai aktivitas guru dalam proses belajar mengajar selama siklus II mengalami peningkatan. Hal ini dapat dilihat dari data hasil observasi terhadap aktivitas guru dalam proses belajar mengajar yang meningkat dari $64,58 \%$ pada siklus I menjadi 89,58 pada siklus II (lihat Lampiran).

3) Hasil analisis deskriptif terhadap nilai evaluasi belajar Kewarganegaraan siswa pada akhir Siklus II dapat dilihat pada tabel berikut:

Tabel 4. Data Statistik Hasil Evaluasi Belajar Kewarganegaraan Siswa pada akhir Siklus II

\begin{tabular}{|l|c|}
\hline Statistik & Jumlah \\
\hline Banyaknya subyek penelitian & 30 \\
\hline Nilai rata-rata & 84,33 \\
\hline Standar deviasi & 11,32 \\
\hline Nilai tertinggi & 100 \\
\hline Nilai terendah & 56 \\
\hline Jumlah siswa yang mencapai KKM & 28 \\
\hline Nilai afektif & Sangat Tinggi \\
\hline
\end{tabular}


d. Refleksi

Keberhasilan yang dicapai pada siklus II adalah sebagai berikut:

1) Meningkatnya aktivitas siswa dalam proses pembelajaran yang menerapkan variasi model pembelajaran moduler dengan MFL. Hal ini dapat dilihat dari data hasil observasi terhadap aktivitas siswa yang meningkat dari $69,92 \%$ pada siklus I menjadi $81,58 \%$ pada siklus II.

2) Meningkatnya aktivitas guru dalam proses belajar mengajar yang sangat berperan dalam meningkatkan aktivitas siswa. Hal ini dapat dilihat dari data hasil observasi terhadap aktivitas guru dalam proses belajar mengajar yang meningkat dari $64,58 \%$ pada siklus I menjadi 89,58 pada siklus II.

3) Meningkatnya nilai rata-rata ulangan harian siswa, yaitu dari 70,07 pada siklus I menjadi 84,33 pada siklus II. Perolehan nilai rata-rata 70,07 dan 84,33 sudah melampaui nilai standar KKM yaitu 70.

\section{Pembahasan}

Dari hasil penelitian pada siklus I dan siklus II, terungkap bahwa penerapan model pembelajaran moduler dan model pembelajaran mfl secara bervariasi dalam pembelajaran Kewarganegaraan dapat meningkatkan aktivitas belajar siswa yang meliputi minat mengerjakan modul, kreativitas mengerjakan modul, kemandirian mengerjakan modul, menyelesaikan modul tepat waktu, mutu hasil modul, minat mengikuti diskusi MFL, mengajukan pendapat/ tanggapan, mencatat hal penting tentang diskusi, mentaati aturan diskusi, dan mutu hasil diskusi.

Peningkatan aktivitas belajar siswa dari siklus I sampai dengan siklus II dapat diamati dari tabel 5 di bawah ini. Dari tabel tersebut dapat dilihat data hasil observasi terhadap aktivitas siswa meningkat dari $69,92 \%$ pada siklus I menjadi $81,58 \%$ pada siklus II. Artinya, aktivitas siswa dalam proses belajar mengajar meningkat dari kategori sedang menjadi kategori tinggi.

Tabel 5 Perbandingan Persentase Skor Aktivitas Siswa dalam Proses Belajar Mengajar Kewarganegaraan pada Siklus I dan Siklus II

\begin{tabular}{|l|c|c|}
\hline \multirow{2}{*}{\multicolumn{1}{|c|}{ Jenis Aktivitas Siswa }} & \multicolumn{2}{c|}{ Persentase Skor (\%) } \\
\cline { 2 - 3 } & Siklus I & Siklus 11 \\
\hline \multirow{2}{*}{ Minat mengerjakan modul } & 76,67 & 90 \\
\hline Kreativitas mengerjakan modul & 73,33 & 72,50 \\
\hline Kemandirian mengerjakan modul & 75,83 & 79,17 \\
\hline Menyelesaikan modul tepat waktu & 70,83 & 83,33 \\
\hline Mutu hasil modul & 75 & 86,67 \\
\hline Minat mengikuti diskusi VCT & 75 & 80,83 \\
\hline Mengajukan pendapat/ tanggapan & 65 & 74,17 \\
\hline Mencatat hal penting tentang diskusi & 61,67 & 79,17 \\
\hline Mentaati aturan diskusi & 72,50 & 94,17 \\
\hline Mutu hasil Diskusi & 53,33 & 75,83 \\
\hline
\end{tabular}




\begin{tabular}{|l|c|c|}
\hline Rata-rata & 69,92 & 81,58 \\
\hline
\end{tabular}

Selain itu, yang tak kalah pentingnya adalah meningkatnya prestasi belajar siswa. Peningkatan prestasi belajar siswa dari siklus I sampai dengan siklus II dapat diamati dari tabel 6 di bawah ini.

Tabel 6. Perbandingan Prestasi Belajar Siswa dalam Proses Belajar Mengajar Kewarganegaraan pada Siklus I dan Siklus II

\begin{tabular}{|l|l|l|}
\hline \multirow{2}{*}{ Statistik } & \multicolumn{2}{c|}{ Prestasi Belajar Siswa } \\
\cline { 2 - 3 } & \multicolumn{1}{|c|}{ Siklus I } & Sikius 11 \\
\hline Nilai Rata-rata & 70,07 & 84,33 \\
\hline Standar Deviasi & 17,21 & 11,32 \\
\hline Nilai Terendah & 40 & 56 \\
\hline Nilai Tertinggi & 92 & 100 \\
\hline Jumlah siswa yang mencapai & 21 & 28 \\
\hline Nilai Afektif & Tinggi & Sangat Tinggi \\
\hline
\end{tabular}

Dari tabel di atas, dapat dilihat bahwa nilai rata-rata hasil penilaian kognitif siswa meningkat dan mencapai KKM, yaitu dari 70,07 pada siklus I menjadi 84,33 pada siklus II. Sedangkan nilai terendah dan nilai tertinggi pada siklus I masingmasing 40 dan 92, dan pada siklus II nilai terendah dan nilai tertinggi masing-masing 56 dan 100. Di samping itu, terdapat pula peningkatan jumlah siswa yang mencapai KKM, yaitu dari 21 siswa pada siklus I menjadi 28 siswa pada siklus II. Hasil-hasil ini mengindikasikan bahwa kemampuan siswa dalam penguasaan materi pelajaran mengalami peningkatan. Nilai afektif siswajuga meningkat, yaitu dari kategori tinggi pada siklus I menjadi kategori sangat tinggi pada siklus II.

Dengan adanya peningkatan kedua indikator tersebut, yaitu aktivitas belajar dan prestasi belajar yang melampaui KKM $(84,33>70)$ pada siklus II, maka dapat dikatakan bahwa penerapan model pembelajaran moduler dan model pembelajaran MFL secara bervariasi, dapat mengefektifkan pembelajaran Kewarganegaraan.

Adanya hasil-hasil positif yang telah dicapai siswa seperti dikemukakan di atas, bila direfleksi kembali ternyata penyebabnya di samping karena meningkatnya aktivitas belajar siswa secara kuantitas dan kualitas, juga berkaitan dengan meningkatnya aktivitas guru dalam mengelola proses pembelajaran yang menerapkan model pembelajaran moduler dengan model pembelajaran MFL secara bervariasi.

\section{KESIMPULAN}

Berdasarkan hasil penelitian tindakan kelas, maka dapat ditarik beberapa kesimpulan sebagai berikut:

1. Penerapan model pembelajaran moduler dan MFL secara bervariasi dalam pembelajaran Kewarganegaraan dapat meningkatkan aktivitas belajar siswa yang meliputi minat 
mengerjakan modul, kreativitas mengerjakan modul, kemandirian mengerjakan modul, menyelesaikan modul tepat waktu, mutu hasil modul, minat mengikuti diskusi MFL, mengajukan pendapat/ tanggapan, mencatat hal penting tentang diskusi, mentaati aturan diskusi, dan mutu hasil diskusi.

2. Penerapan model pembelajaran moduler dan model pembelajaran MFL secara bervariasi dapat mengefektifkan pembelajaran Kewarganegaraan. Hal ini dapat dilihat data hasil observasi terhadap aktivitas siswa yang meningkat dari $69,92 \%$ pada siklus I menjadi $81,58 \%$ pada siklus II dan nilai rata-rata hasil penilaian kognitif siswa yang juga meningkat dan mencapai KKM, yaitu dari 70,07 pada siklus I menjadi 84,33 pada siklus II.

3. Peranan guru dalam proses belajar mengajar yang menerapkan model pembelajaran moduler dan model pembelajaran MFL sangat penting sebagai pendukung peningkatan aktivitas belajar siswa dan peningkatan prestasi belajar.

\section{DAFTAR PUSTAKA}

Kunandar. (2008). Penelitian Tindakan Kelas sebagai Pengembangan Profesi Guru. Jakarta: PT. Rajadrafindo Persada.

Oemar Hamalik. (2007). Proses Belajar Mengajar. Jakarta: PT. Bumi Aksara.

Pemerintah Prov. Sulsel \& Tim Pengembang Pembelajaran Efektif UNM. (2005). Panduan Praktis Model Pembelajaran Efektif Sekolah Menengah Atas. Makassar: Pemprov.Sulsel-UNM.

Pupuh Faturrahman \& M. Sobry Sutikno. (2007). Strategi Belajar Mengajar melalui Penanaman Konsep Umum dan Konsep Islam. Bandung: PT. Refika Aditama.

Sanjaya, Wina. (2006). Strategi Pembelajaran Berorientasi Standar Proses Pendidikan. Jakarta: Kencana Prenada Media Group.

Suharsimi Arikunto, dkk. (2007). Penelitian Tindakan Kelas. Jakarta: PT.Bumi Aksara.

Syaiful Bahri Djamarah \& Azwan Zain. (2002). Strategi Belajar Mengajar. Jakarta: Rineka Cipta.

Uno, Hamzah B. (2007). Model Pembelajaran (Menciptakan Proses Belajar Mengajar yang Kreatifdan Efektif). Jakarta: PT. Bumi Aksara. 